\title{
КЛІНІКО-ПСИХОЛОГІЧНІ ОСОБЛИВОСТІ ДІТЕЙ З РІЗНИМИ ФОРМАМИ ОЖИРІННЯ
}

\author{
Михайлова Е. А. ${ }^{1}$, Кукуруза Г. В. ${ }^{1}$, Шестопалова Л. Ф. ${ }^{2}$, Підкоритов В. С. ${ }^{2}$, \\ Кришталь С. В. ${ }^{3}$, Матковська Т. М. ${ }^{1}$, Мітельов Д. А. ${ }^{1}$, Нікітіна Л. Д. ${ }^{1}$ \\ ${ }^{1}$ ДУ «Інститут охорони здоров'я дітей та підлітків НАМН Украйни», Харків, Україна; \\ ${ }^{2}$ ДУ «Інститут неврологї, психіатрї та наркологї НАМН Украйни», Харків, Україна; \\ ${ }^{3}$ Харківська медична академія післядипломної освіти, Харків, Украйна \\ avkukuruza62@gmail.com
}

В останні роки ожиріння е одним із самих розповсюджених хронічних захворювань у світі. За даними ВОЗ, на початок XXI сторіччя ожиріння відзначалось у $30 \%$ населення планети. Майже у $60 \%$ дорослих [1-3]. Дитяче та підліткове ожиріння, яке продовжуеться у дорослому віці, відзначаеться більш важким перебігом, збільшеною частотою супутніх захворювань, ніж ожиріння, яке дебютувало у дорослому віці [46]. Простежено взаємозв'язок ожиріння та цукрового діабету 1 типу та їх роль у формуванні неврологічних ускладнень у дітей та підлітків [7, 8].

Ожиріння у дитячому віці призводить до низки психологічних та соціальних ускладнень, до яких передусім відносять формування психологічного стресу, низьку самооцінку, невдоволення тілом, депресію, появу суїцидальних думок, втрату контролю над харчуванням, нездорову та екстремальну поведінку щодо контролю ваги, порушення соціальних зв'язків, стигматизацію та зниження якості життя, пов’язаної зі здоров’ям [9]. Згідно літературних даних, психічні розлади фіксуються у 40,6\% дітей 3 ожирінням, в структурі яких переважають тривожні розлади [10].

Вивчення впливу «екстремального» ожиріння на психологічне функціонування дітей показало позитивні кореляції між ступенем ожиріння, психологічним функціонуванням та якістю життя [11]. У дітей з ожирінням низький рівень задоволеності тілом корелював із рівнем депресії, незадоволення тілом опосередковувало зв'язок між ожирінням та самооцінкою. Діти з ожирінням, які були незадоволені тілом, мали

* Роботу виконано згідно з науковою тематикою ДУ «Інститут охорони здоров’я дітей та підлітків НАМН України» «Вивчити роль інсулінорезистентності в формуванні ураження органів та систем при ожирінні у дітей та підлітків», (державний реестраційний № 0111U001588).

Установою, що фінансуе дослідження, е НАМН України.

Автори гарантують відповідальність за все, що опубліковано в статті.

Автори гарантують відсутність конфлікту інтересів та власної фінансової зацікавленості при виконанні роботи та написанні статті.

Рукопис надійшов до редакції 10.02.2021. 
гіршу самооцінку та більш високий рівень депресивних переживань, у порівнянні з тими пацієнтами, які позитивно ставилися до свого тіла [12]. У дітей з ожирінням відзначаються більш високі рівні тривоги, депресії, порушення емоційної сфери та комунікативно-міжособистісних взаємовідносин, акцентуації характеру, наявність різних розладів психологічного розвитку [13].

Важливим соціально-психологічним аспектом ожиріння у дітей та підлітків виступає ризик їх віктимізації. Надмірна вага та ожиріння, пов'язані з помітними відмінностями у зовнішньому вигляді, можуть провокувати булінг у вигляді різних фрорм переслідувань, знущань, проявів зневаги, адже для однолітків такі діти виглядають як несхожі та небажані $[14,15]$. До того ж, переслідування посилюють негативне самосприйняття, погіршують самооцінку під- літків 3 ожирінням й спричинюють появу депресії. Ці явища перешкоджають соціальному та психологічному розвитку як у найближчій так і в довгостроковій перспективі [16].

Поширеність ожиріння і масштабність його впливу на соматичне та психічне здоров'я, психологічне благополуччя і соціальну адаптацію в дитячому віці не викликає сумнів. Вивчення чинників, які мають вплив на формування особливостей психологічного розвитку дітей для підвищення ефрективності лікування та фрормування ефрективних моделей поведінки, пов'язаною з ожирінням, стає важливим науково-практичним завданням медичної психології.

Метою дослідження було визначення особливостей формування та чинників ризику порушень психічного розвитку у дітей з різними формами ожиріння.

\section{МАТЕРІАЛИ ТА МЕТОДИ}

У дослідженні брали участь 304 дитини віком 7-18 років, хворих на ожиріння (107 хлопців та 197 дівчат), які перебували на стаціонарному лікуванні у відділенні ендокринології ДУ «Інститут охорони здоров’я дітей та підлітків НАМН України».

Використовувались антропометричний, біохімічний, клініко-психопатологічний, клініко-анамнестичний, психодіагностичний та математико-статистичний методи.

Для визначення клінічної форми ожиріння використовувалась класифікація, наведена у Протоколах надання медичної допомоги дітям за спеціальністю «Дитяча ендокринологія» [17]. Антропометрія використовувалась для встановлення клінічної форми ожиріння та включала визначення росту, маси тіла, обводу талії (ОТ) та стегон (ОC), співвідношення ОТ/ОС. Тип ожиріння визначався за показниками ОТ та ОТ/OC (при перевищенні ОТ 95 перцентилі відповідних вікових нормативів та/або при ОТ/ OC більше 0,9 у хлопців і ОT/OC більше 0,85 у дівчат діагностували абдомінальне (андроїдне) ожиріння).

3 метою адекватної оцінки маси тіла застосовувався IMT, що тісно корелюе з загальним вмістом жиру в організмі за формулою:
\[ \mathrm{IMT}=\mathrm{m} / \mathrm{h}^{2}, \]
де $\mathrm{m}$ - маса тіла, кг;
$\mathrm{h}$ - зріст, м.
В дослідження включено хворих з індексами маси тіла, що перевищували 97-у перцентиль для їх віку та статі, серед них було виділено групи в залежності від відсотку надлишку маси тіла (НМТ) відносно $97 \%$ для відповідного віку: при відсотку НМТ до $10 \%$ діагностували ожиріння I ступеня, 11-20\% - II ступеня, більше $20 \%$ - III ступеня .

Для виявлення порушень вуглеводного обміну у хворих з ожирінням уніфікованим глюкозооксидазним методом визначався рівень глюкози крові натще з наступним проведенням стандартного глюкозотолерантного тесту (ГТТ) (навантаження глюкозою у дозі 1,75 г глюкози/кг маси тіла, але не більше 75 г з визначенням глікемії натще та через 60 і 120 хвилин). Оцінка гормонального статусу передбачала визначення в сироватці крові показників імунореактивного інсуліну (IPI).

Індекс IP (НОМА) розраховувався за формулою:

$$
\mathrm{HOMA}=\left(\mathrm{G}_{0} \cdot \mathrm{Ins}_{0}\right) / 22,5 \text {, }
$$

де $\mathrm{G}_{0}$ - рівень глюкози плазми крові натще, ммоль/л; 
$\operatorname{Ins}_{0}$ - вміст IPI в сироватці крові натще, мкО/мл.

Наявність IP у хворих на ожиріння діагностувалась за умови рівня НOMA, вищого ніж 3,5 .

Для оцінки тривожності використовувалась «Методика багатомірної оцінки дитячої тривожності» (МОДТ) [18]. Особливості емоційної та мотиваційної сфрер хворих вивчались за допомогою методики «Колірний тест відношення» [19]. Визначення ставлення до хвороби проводилось з використанням проективного малюнку «Я та моя хвороба». Для визначення наявності та вираженості невротичної симптоматики застосовувався тест рівня невротизації [18]. Статистична обробка результатів проводилась з використанням пакетів прикладних програм Microsoft Excel та SPSS 17.0.

\section{РЕЗУЛЬТАТИ ТА ЇХ ОБГОВОРЕННЯ}

Результати розподілу дітей в залежності від форми, ступеня, типу ожиріння та наявності інсулінорезистентності (IP) представлено в таблиці 1.

У 186 дітей було діагностовано нейроендокринне ожиріння, з них 125 дітей мали ожиріння I-III ступеню 3 андроїдним типом і наявністю IP, 61 дитина - нейроендокринне ожиріння I-II ступеню без IP. У 118 хворих було визначено екзогенно-конституційна форма ожиріння, з них у 12 дітей встановлено ожирінням I-II ступеню за змішаним типом з IP, а у106 дітей - екзогенно-конституційне ожиріння I-II ступеню з гіноїдним та змішаним типом ожирінням без IP.

Ожиріння, що є наразі однією 3 найбільш поширених ендокринопатій у дітей, супроводжується у значної частини хворих зниженням чутливості до інсуліну та порушенням секреторної функції В-клітин, що обумовлює високий ризик формування синдрому IP. Отримані нами дані свідчили про відсутність патологічних змін вуглеводного обміну за даними ГТТ у досліджуваних підлітків з ожирінням, хоча у більшості хворих (76,2\%) відзначався гіперінсуліне- мічний тип кривої. Отже, у дітей та підлітків 3 ожирінням відзначається гіперфрункція В-клітин, і за наявності IP значно перевищуе контрольні показники. Все це сприяє виснаженню інсуліносекреції у хворих на ожиріння дитячого віку та створює передумови для формування значущих порушень вуглеводного обміну в подальшому та розвитку психоневрологічних розладів.

Аналіз даних анамнезу показав, що у більшості досліджуваних хворих (95,1\%) виявилися ознаки підвищеної емоційної збудливості, вразливості, схильності до соматовегетативних проявів (непритомність, запаморочення). При всіх клінічних варіантах ожиріння відзначалися різноманітні ознаки порушень функціонування нервової системи та психічної сфери.

Було проведено оцінку психопатологічних порушень з визначенням їх характеру та частоти виявлення в залежності від клінічної форми ожиріння та наявності порушень чутливості до інсуліну, які визначались за допомогою обчислювання індексу НОМА. Ранжування цих даних дозволило встановити, що у дітей з нейроендокринним ожирінням без IP найбільш часто

Розподіл дітей в залежності від форми, ступеня, типу ожиріння та рівня інсулінорезистентності $(\mathrm{n}=304)$

\begin{tabular}{c|c|c|c}
\hline Група & Клінічна форма & Кількість дітей & \% \\
\hline I & Нейро-ендокринне ожиріння I-III ступеню, \\
андроїдний тип 3 IP & 125 & 41,12 \\
\hline II & Нейроендокринне ожиріння I-II ступеню без IP & 61 & 20,06 \\
\hline III & $\begin{array}{c}\text { Екзогенно-конституційне ожиріння I-II ступеню, } \\
\text { змішаний тип з IP }\end{array}$ & 12 & 3,95 \\
\hline IV & $\begin{array}{c}\text { Екзогенно-конституційне ожиріння I-II ступеню, } \\
\text { гіноїдний та змішаний тип без IP }\end{array}$ & 106 & 34,87 \\
\hline
\end{tabular}


зустрічались тривожно-депресивні порушення $(24,6 \%)$, психовегетативні $(21,4 \%)$, астенічні - у 18,0\% дітей. В групі дітей $з$ нейроендокринним ожирінням 3 IP найчастіше зустрічалися тривожно-депресивні, соматоформні та астенічні порушення $(31,2 \%, 18,4 \%$ та 13,6\% відповідно). При екзогенно-конституційному ожирінні без ознак IP - психовегетативні порушення діагностовано у 33,0\% пацієнтів, а соматоформні та астеничні - 3 однаковою частотою (по 27,4\%). У пацієнтів з екзогенно-конституційним ожирінням 3 IP домінували депресивні розлади $(41,6 \%)$, у $25,0 \%$ - тривожні, а у $16,6 \%$ - астенічні порушення.

В цілому у дітей з ожирінням превалювали астенічні розлади, які діагностувались у 75,5\% обстежених. Клінічно астенія проявлялася від легкої стомлюваності, дратівливості, поверхневого сну до виражених астенічних станів, що порушують адаптацію та соціальне функціонування. Вазовегетативні розлади у підлітків 3 нейроендокринним ожирінням мали переважно характер діенцефральних кризів. Цефалгія, загальний гіпергідроз, стомлюваність, метеозалежність були найбільш частими проявами поганого самопочуття у дітей на тлі емоційних і особистісних проблем, обумовлених негативним сприйняттям надмірної ваги ними самими і peакцією однолітків. Вищезгадані симптоми зустрічались як в групі дітей 3 ожирінням та збереженою чутливістю до інсуліну, так і у хворих з інсулінорезистентністю, однак спостерігалась певна різниця у ступені їх проявів. Так, головний біль відзначався у 67 дітей (48,9\%) з IP та у 48 осіб (28,7\%) з групи хворих зі збереженою чутливістю до інсуліну ( $<<0,01)$. Ознаки церебрального венозного застою в групі дітей з ожирінням без IP були обмежені субклінічною формою. У 18,2\% дітей з IP відзначалося підвищення внутрішньочерепного тиску у вигляді субклінічних проявів випадків, у 8,7\% - легкого ступеня тяжкості, у 3,6\% середнього. Така симптоматика виявлялась у 10,7\% дітей з ожирінням без IP, але лише в межах субклінічної форми. Таким чином, інсулінорезистентність виступала у якості загального чинника, що має суттєвий вплив на церебральну гемодинаміку та вегетативні регуляторні механізми у дітей з ожирінням.

Аналіз клініко-психопатологічних особливостей дітей показав, що депресивні переживання відмічались у 63,8\% дітей 3 ожирінням та проявлялись у вигляді смутку, туги, дратівливості, ангедонії, порушень сну, загальмованості, зниження енергії, почуття нікчемності або провини. Багато з них вважали, що мають нормальний або навіть знижену вагу, що, з одного боку, сприяло підтримці самооцінки в ситуації хвороби, з іншого - виявлялося перешкодою в лікуванні, знижуючи мотивацію і послаблюючи комплаєнс. У хворих на ожиріння встановлено відмінності в структурі емоційних розладів в залежності від наявності IP. Так при наявності IP депресивні порушення відзначались у 25,2\%,

Рівень інсулінемії у хворих з різними формами психопатологічних порушень, (п= 304$), \mathrm{M} \pm \mathrm{m}$

\begin{tabular}{c|c|c|c|c}
\hline Показники & $\begin{array}{c}\text { Тривожні } \\
\text { розлади }\end{array}$ & $\begin{array}{c}\text { Депресивні } \\
\text { розлади }\end{array}$ & $\begin{array}{c}\text { Тривожно- } \\
\text { депресивні } \\
\text { розлади }\end{array}$ & $\begin{array}{c}\text { Астенічні та } \\
\text { психовегетативні } \\
\text { порушення }\end{array}$ \\
\hline $\mathrm{n}$ & 58 & 95 & 41 & 110 \\
\hline $\mathrm{IPI}, \mathrm{M \kappa O/мл}$ & $20,0 \pm 1,0$ & $21,6 \pm 1,8$ & $24,3 \pm 3,4^{*}$ & $17,7 \pm 1,1^{*}$ \\
\hline НОМА & $4,3 \pm 0,2$ & $4,8 \pm 0,4$ & $5,2 \pm 0,7^{* *}$ & $3,8 \pm 0,3^{* *}$ \\
\hline
\end{tabular}

\section{Прилітки:}

* відмінність показника IPI між дітьми з тривожно-депресивними та астенічними і психовегетативними порушеннями на рівні $\mathrm{p}<0,05$;

** відмінність показника НОМА між дітьми з тривожно-депресивними та астенічними і психовегетативними порушеннями на рівні $\mathrm{p}<0,05$. 
а без IP у 6,7\% дітей з ожирінням ( $<<0,05)$. Тривожні порушення фіксувались у 16,1\% хворих з IP та у 9,1\% без IP (p<0,05).

Результати визначення рівня інсулінемії у дітей з ожирінням з різними формами психопатологічних порушень представлено в таблиці 2.

Таким чином, наявність порушень вуглеводного обміну у дітей з ожирінням $є$ чинником, який сприяе появі різних емоційних порушень та їх несприятливому перебігу.

Дані психодіагностичного дослідження дозволили встановити у 66,7\% дітей невдоволеність потреби в емоційно-теплих стосунках з оточуючими. Невротичний рівень реагування на хворобу визначено у $60 \%$ дітей, порушення формування довільно-регулятивний процесів - у 82,6\%. Зображення ознак зайвої ваги в автопортретних малюнках, яке відображало уявлення про власне захворювання, реєструвалося у 38,4\% дітей. Такі зображення вірогідно частіше продукували хлопчики ніж дівчата (відповідно, 62,5\% та 19,5\%; р < 0,001). Настільки значний гендерний розрив у частоті асоційованих 3 надмірною вагою автопортретних зображень відбивав розходження в самоприйнятті свого тіла між хлопчиками й дівчатками й свідчив, що повним дівчинкам набагато сутужніше приймати своє тіло. Тривожна напруга, яка виявлялася в графічних характеристиках, реєструвалася в половині малюнків дівчаток, але у хлопчиків відзначалася вдвічі рідше (відповідно, 51,2\% та 25,0\%; р < 0,001). Переживання страху й ворожості вірогідно частіше виявлялося в малюнках хлопчиків (відповідно, 21,9\% та 7,3\%; р < 0,04). Психологічні ознаки домінуючого тривожного реагування на різні події були виявлені у 33,3\% обстежених хворих, та максимально виражені у дітей, коли ожиріння поєднувалось з IP.

Встановлено, що психологічні показники депресії і тривоги були максимально виражені у дітей з ожирінням та інсулінорезистентністю (при значенні НОМА > 3,5). Наявність інсулінорезистентності у дітей $€$ значущим чинником, який сприяє появі різних емоційних порушень та їх несприятливому перебігу.
Комплексне клініко-психопатологічне та клініко-психологічне дослідження дозволило визначити, що у дітей з ожирінням на тлі знижених адаптаційних можливостей у вигляді порушень фрункціонування церебральних структур, які можуть підсилюватися психосоціальними стресами, формуються різноманітні особистісно-реактивні зміни. Типологія реакцій у цієї когорти дітей з ожирінням включала: ігнорування актуальних проблем, пов'язаних з вагою, формування типових особистісних властивостей, психологічну агнозію або реакції гіперкомпенсації, а також особистісно-реактивні зміни у вигляді депресії 3 тяжкими переживаннями фрізичного дефекту. Неконтрольоване прагнення вживати велику кількість їжі в подальшому формували залежний тип харчової поведінки. Типовими психологічними характеристиками всіх дітей з ожирінням були зниження самооцінки, порушення міжособистісної взаємодії в різних соціальних контекстах, дефіцит комунікативних ресурсів, емоційні порушення у вигляді депресивних та тривожних переживань. У більшості пацієнтів з ожирінням депресивні та тривожні переживання підтримувались досвідом переслідувань з боку однолітків через зовнішність, а саме, відкритими формами агресивного ставлення у вигляді фізичної агресії, глузування, образливих прізвиськ, та непрямою агресією - плітками, позбавленням уваги, виключенням з кола дружнього спілкування. Однак слід підкреслити, що у частини дітей з ожирінням відсутні ознаки порушень психічного розвитку. Вони характеризуються адекватною самооцінкою, відповідним уявленням про своє тіло, адаптовані в соціумі, не мають ознак самостигматизації, яка пов'язана із зовнішністю.

Таким чином, встановлено, що у дітей 3 ожирінням та IP спостерігаються різноманітні варіанти порушень їх психічного розвитку та психічного здоров'я в цілому. Недооцінка наявності та характеру психопатологічних розладів посилює ризики прогресування ендокринного захворювання. Клініко-психологічні особливості дітей з ожирінням представлені складним симптомокомплексом, який включає зниження 
самооцінки, порушення міжособистісної взаємодії в різних соціальних контекстах, дефіцитарність комунікативних ресурсів, викривлення сприйняття власного тіла, порушення харчової поведінки, не сорормованість довільно-регуляторних механізмів, емоційні та мотиваційні зміни. Існують певні гендерні відмінності, а саме, дівчатам 3 ожирінням притаманні більш виражені прояви тривожних переживань, пов’язаних із сприйняттям своеї зовнішності; хлопчикам - почуття страху та ворожості, як загальна реакція на актуальний психосоціальний стрес.
Ідентифіковано комплекс психосоціальних чинників, який здійснює патогенний вплив на психічний розвиток дитини з ожирінням. Діти з ожирінням розвиваються в особливій соціальній ситуації розвитку, яка характеризується наявністю очевидних зовнішніх ознак захворювання, що відрізняе їх від однолітків, викривленням образу власного тіла та станами психоемоційного напруження, різними, в тому числі, деструктивними формами реагування оточуючих на дитину та складними явищами стигматизації і самостигматизації.

\section{ВИСНОВКИ}

1. Встановлено, що нейро-ендокринне ожиріння I-III ступеню зустрічалось частіше і відзначалось у $61,18 \%$ обстежених в порівнянні екзогенно-конституційним ожирінням I-II ступеню, яке діагностувалось у 38,82\% хворих. Порушення чутливості до інсуліну у вигляді синдрому IP було більш притаманне нейро-ендокринному ожирінню і діагностувалось у 41,12\% обстежених в порівнянні з екзогенно-конституційним (3,95\%).

2. У дітей з різними клінічними формами ожиріння домінували астенічні розлади $(75,5 \%)$, які коливались в діапазоні від доклінічних проявів до виражених астенічних станів, що створювали підгрунтя для порушення їх соціально-психологічної адаптації та функціонування. У пацієнтів з екзогенно-конституційним ожирінням, обтяженим інсулінорезистентністю, переважали депресивні (41,6\%), а без наявності ознак інсулінорезистентності - психовегетативні (33,0\%) порушення. Депресивні та тривожні розлади домінували в структурі порушень емоційної сфери, при цьому така симптоматика була більш вираженою у хворих на ожиріння, поєднане з інсулінорезистентністю.

3. Своєчасна діагностика психічних розладів, в тому числі на субклінічному рівні, визначення психологічних проблем дітей $з$ ожирінням, дозволяе вибирати тактику психотерапевтичного втручання на ранньому етапі ендокринологічного захворювання для формування у хворих стратегій поведінки, спрямованих на зменшення тяжкості перебігу патології.

\section{ЛITEPATУPA \\ (REFERENCES)}

1. Caprio S, Santoro N, Weiss R. Nat Metab 2020; 2: 223 232. doi: https://doi.org/10.1038/s42255-020-0183-z.

2. Mandy Geserick, et al. N Engl J Med 2018; 379: 13031312. doi: https://doi.org/10.1056/NEJMoa1803527.

3. Shanshan Li, et al. Int J Epidemiol 2017; 46(5): 15331541. doi: https://doi.org/10.1093/ije/dyx151

4. Dennis M. Styne, et al. J Clin Endocrinol Metab 2017; 102(3): 709-757. doi: https://doi.org/10.1210/jc. 2016-2573.

5. Ciro Andolfi, Marco Fisichella P. J Laparoendoscopic Advanced Surg Techniq 2018; 28(8). doi: https://doi. org/10.1089/lap.2018.0380.

6. Davis CL, et al. Am J Med Sci 2002; 324(2): 72-75.
7. De Keukelaere M, Fieuws S, Reynaert N, et al. Eur $J$ Pediatr 2018; 177: 1661-1666, doi: https://doi.org/10. 1007/s00431-018-3224-9.

8. O'Brien D, et al. The Lancet. Neurology 2017;16(6): 465477. doi: https://doi.org/10.1016/S1474-4422(17)30084-4.

9. Vander Wal JS, Mitchell ER. Psychol Compl Pediatr Obes http://www.ncbi.nlm.nih.gov/pubmed/19916639 2011; 58(6): 1393-1401.

10. Vila G, Zipper E, Dabbas M, et al. Psychosom Med 2004; 66(3): 387-394.

11. Phillips BA, et al. J Clin Psychol Med Settings 2012; 55: 1290-1298.

12. Shin NY, Shin MS. J Pediatr 2008; 152(4): 502-506. 
13. Bekezin VV, et al. Pediatrija 2008; 87(5): 30-36.

14. Robinson S. J Sch Nurs 2006; 22(4): 201-206.

15. Eisenberg M, Neumark-Sztainer D. Int J Adolesc Med Health 2008; 20(2): 155-164.

16. Adams RE, Bukowski WM. J Child Psychol Psychiatry 2008 ; 49(8): 858-866.

17. Protokol nadannja medychnoji dopomogy ditjam za spetsial'nist'ju «Dyt'acha endokrynologija» / pid red. Zelens'koji NB, Kyi'v, 2006: 94 p.
18. Malkova EE. Psihodiagnosticheskaja metodika dlja mnogomernoj ocenki detskoj trevozhnosti: posobie dlja vrachej i psihologov, Sankt-Peterburg, 2008: 35 p.

19. Jetkind AM. Cvetovoj test otnoshenij i ego primenenie $\mathrm{k}$ issle-dovaniju bol'nyh nevrozami. Social'no-psihologicheskie issledovanija $\mathrm{v}$ psihonevrologii / pod red. Bazhina EF, Moskva, 1980: 110-114.

\section{КЛІНІКО-ПСИХОЛОГІЧНІ ОСОБЛИВОСТІ ДІТЕЙ 3 РІЗНИМИ ФОРМАМИ ОЖИРІННЯ}

Михайлова Е. А. ${ }^{1}$, Кукуруза Г. В. ${ }^{1}$, Шестопалова Л. Ф. ${ }^{2}$, Підкоритов В. С. ${ }^{2}$, Кришталь С. В. ${ }^{3}$, Матковська Т. М., Мітельов Д. А. ${ }^{1}$, Нікітіна Л. Д. ${ }^{1}$

${ }^{1}$ ДУ «Інститут охорони здоров'я дітей та підлітків НАМН України», Харків, Україна;

${ }^{2}$ ДУ "Інститут неврологї, психіатрї та наркологї НАМН Украӥни», Харків, Україна;

${ }^{3}$ Харківська медична академія післядипломної освіти, Харків, Україна avkukuruza62@gmail.com

Метою дослідження було визначення особливостей формування та чинників ризику порушень психічного розвитку у дітей з різними формами ожиріння. У дослідженні брали участь 304 дитини віком 7-18 років, хворих на ожиріння, які в залежності від форми, ступеня, типу ожиріння та наявності інсулінорезистентності (IP) були розподілені на 4 групи. Переважало нейро-ендокринне ожиріння I-III ступеню з андроїдним типом і наявністю IP $(41,12 \%)$ та екзогенно-конституційне без IP (34,87\%). Найрідше діагностувалось екзогенно-конституційне ожиріння з IP (3,95\%). Оцінка психопатологічних порушень з визначенням їх характеру та частоти в залежності від клінічної форми ожиріння дозволила встановити переважання емоційних порушень у дітей 3 нейроендокринним ожирінням, незалежно від рівня інсулінорезистентності. У дітей з різними клінічними формами ожиріння домінували астенічні розлади (75,5\%), які коливались в діапазоні від доклінічних проявів до виражених астенічних станів, що створювали підгрунтя для порушення їх соціальнопсихологічної адаптації та фрунціонування. У пацієнтів з екзогенно-конституційним ожирінням, обтяженим інсулінорезистентністю переважали депресивні (41,6\%), а без наявності ознак інсулінорезистентності - психовегетативні (33,0\%) порушення. Депресивні та тривожні розлади домінували в структурі порушень емоційної сфрери, при цьому така симптоматика була більш вираженою у хворих на ожиріння, поєднане з інсулінорезистентністю. Наведена змістовна характеристика складного симптомокомплексу клініко-психологічних особливостей дітей з ожирінням та показана наявність певних гендерних відмінностей. Виділено комплекс психосоціальних чинників, який здійснюе патогенний вплив на психічний розвиток дитини з ожирінням. Діти 3 ожирінням розвиваються в особливій соціальній ситуації розвитку, яка характеризується складними явищами стигматизації і самостигматизації: наявністю очевидних зовнішніх ознак захворювання, що відрізняе їх від однолітків, викривленням образу власного тіла та станами психоемоційного напруження, різними, в тому числі, деструктивними формами реагування оточуючих на дитину.

К л ючові с лов а: ожиріння, діти, психічний розвиток, емоційна сфера, психосоціальні чинники. 


\title{
CLINICAL AND PSYCHOLOGICAL CHARACTERISTICS OF CHILDREN WITH VARIOUS FORMS OF OBESITY
}

\author{
Mykhailova I. A. ${ }^{1}$, Kukuruza G. V. ${ }^{1}$, Shestopalova L. F. ${ }^{2}$, Pidkorytov V. S. ${ }^{2}$, \\ Kryshtal E. V. ${ }^{3}$, Matkovska T. M. ${ }^{1}$, Mitelov D. A ${ }^{1}$, Nikitina L. D. \\ ${ }^{1}$ State Institution "Institute of Child and Adolescent Health Care of the NAMS of Ukraine", \\ Kharkiv, Ukraine; \\ ${ }^{2}$ State Institution "Institute of Neurology, Psychiatry and Narcology of the NAMS of Ukraine», \\ Kharkiv, Ukraine; \\ ${ }^{3}$ Kharkiv Medical Academy of Postgraduate Education, Kharkiv, Ukraine \\ avkukuruza62@gmail.com
}

Purpose of the study is to determine the features of mental disorders formation and risk factors in children with various forms of obesity. The study involved 304 obese children aged 7-18 years which depending on the form, degree, type of obesity and the presence of insulin resistance (IR) were divided into 4 groups. Neuroendocrine obesity of the I-III degree with android type and presence of IR (41.12\%) and exogenous-constitutional without IR (34.87\%) prevailed. Exogenous-constitutional obesity with IR was the least frequently diagnosed (3.95\%). Assessment of psychopathological disorders with determination of their nature and frequency depending on the clinical form of obesity allowed to establish the predominance of emotional disorders in children with neuroendocrine obesity, regardless of the insulin resistance level. Children with various clinical forms of obesity were dominated by asthenic disorders (75.5\%), which ranged from preclinical manifestations to pronounced asthenic conditions, which created the basis for disruption of their socio-psychological adaptation and functioning. Patients with exogenous constitutional obesity burdened with insulin resistance were dominated by depressive (41.6\%), and without signs of insulin resistance - psychovegetative (33.0\%) disorders. Depressive and anxiety disorders dominated the structure of emotional disorders, while such symptoms were more pronounced in obese patients combined with insulin resistance. A meaningful description of the complex symptom complex of clinical and psychological characteristics of obese children is given and the presence of certain gender differences is shown. A complex of psychosocial factors that have a pathogenic effect on the mental development of an obese child is identified. Obese children are developed in a special social situation of development, which is characterized by complex phenomena of stigmatization and self-stigmatization: the presence of obvious external signs of the disease that distinguishes them from their peers, distortion of their own body image and states of psychoemotional tension, various, including destructive forms of reaction of others to the child.

Keywords: obesity, children, psychical development, emotional sphere, psychosocial factors. 